\title{
Cupriferous pseudobrookite in a Tertiary basalt from the Faeroe Islands
}

\author{
AAGE JENSEN
}

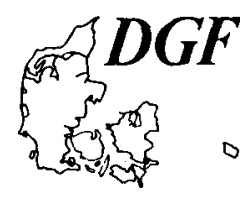

Jensen, Aa.: Cupriferous pseudobrookite in a Tertiary basalt from the Faeroe Islands. Bull. geol. Soc. Denmark, vol. 34, pp. 87-95, Copenhagen, December, 19th, 1985. https://doi.org/10.37570/bgsd-1985-34-09

\begin{abstract}
Forty-five electron microprobe analyses have been carried out on pseudobrookite occurring in a basalt from the Faeroe Islands. It is shown that pseudobrookite formed after ilmenite contains between 1 and $3 \% \mathrm{CuO}$, whereas pseudobrookite formed after titanomagnetite does not contain $\mathrm{Cu}$. This difference in $\mathrm{Cu}$ content is not inherited from the original ilmenite and titanomagnetite, but arises during the formation of the pseudobrookite.

The pseudobrookite in this basalt, regardless of whether it formed from ilmenite or from titanomagne-tite, is richer in $\mathrm{Ti}$ than in the formula $\mathrm{Fe}_{2} \mathrm{TiO}_{5}$, the surplus $\mathrm{Ti}^{4+}$ being balanced by the presence of divalent ions such as $\mathrm{Mg}, \mathrm{Mn}, \mathrm{Fe}$ and $\mathrm{Cu}$. $\mathrm{Mg}$ and $\mathrm{Cu}$ dominate in pseudobrookite after ilmenite, $\mathrm{Fe}$ and $\mathrm{Mg}$ domi-nate in pseudobrookite after titanomagnetite. Pseudobrookite after titanomagnetite is richer in Ti than pseudobrookite after ilmenite.

The pseudobrookite is not homogeneous. Both pseudobrookite formed from ilmenite and that formed from titanomagnetite contain small blebs of hematite and rutile, and furthermore pseudobrookite after ti-tanomagnetite is intergrown with larger coherent areas of hematite. The hematite blebs in pseudobrookite after ilmenite can contain up to more than $5 \% \mathrm{CuO}$, but there is virtually no copper in either type of he-matite in the pseudobrookite after titanomagnetite, nor do the rutile blebs contain copper.
\end{abstract}

Aage Jensen, Institute of Mineralogy, University of Copenhagen, Øster Voldgade 10, DK-1350 Copenhagen K., Denmark, October 4th, 1984.

\section{Introduction}

The petrology of the $3000 \mathrm{~m}$ thick sequence of early Tertiary basalt lavas that make up the Faeroe Islands has been described by Noe-Nygaard \& Rasmussen (1968), and a geological map of the Faeroe Islands was issued in 1969 (Rasmussen \& Noe-Nygaard 1969). The $3000 \mathrm{~m}$ pile of basaltic lava is divided into three series: the lower series, the middle series and the upper series (Noe-Nygaard 1962). The lower series comprises $900 \mathrm{~m}$ of mainly aphyric quartz tholeiitic basalts and is separated from the middle series by a $15 \mathrm{~m}$ thick sedimentary coal-bearing sequence. The average thickness of single lava flows in the lower series is about $20 \mathrm{~m}$, whereas individual flows in the middle series, which comprises $1350 \mathrm{~m}$ of mainly porphyritic quartz tholeiitic basalts, are considerably thinner, having thicknesses down to $10 \mathrm{~cm}$. The upper series comprises $675 \mathrm{~m}$ of mainly olivine tholeiitic basalts; single flows are about $10 \mathrm{~m}$ in thickness.

Mineralogical and geochemical variations across single lava flows (one flow from each of the three series) were investigated by Jensen $(1978,1980)$ and the same author investigated the distribution of $\mathrm{Cu}$ across the same three flows (Jensen 1982). Two of the flows contain about $200 \mathrm{ppm} \mathrm{Cu}$, whereas the third contains about $100 \mathrm{ppm} \mathrm{Cu}$. A negligible amount of $\mathrm{Cu}$ is bound in sulphides, somewhat more occurs as native $\mathrm{Cu}$, but most of the $\mathrm{Cu}$ content is either loosely bound in material with ion-exchange properties such as zeolites, or lattice-bound mainly in Fe-Tioxides.

The amount of lattice-bound $\mathrm{Cu}$ is largest where the oxidation has reached stage 6 or 7 (Haggerty 1976) and the Fe-Ti-oxides are represented by pseudobrookite-hematite-rutile intergrowths. The $\mathrm{Cu}$ preferentially occurs in pseudobrookite and the amount of $\mathrm{Cu}$ present can be as high as $\mathbf{2 . 4 \%}$. These results were obtained with a Hitachi XMA-5B electron microprobe. Pseudobrookite has long been known to contain varying amounts of $\mathrm{Ti}^{4+}, \mathrm{Fe}^{3+}, \mathrm{Al}^{3+}, \mathrm{Fe}^{++}$and $\mathrm{Mg}^{++}$- for example Smith (1965) reported pseudobrookite with up to almost $8 \% \mathrm{Al}_{2} \mathrm{O}_{3}$ - but Jensen (1982) was the first to report pseudobroo- 
kite containing a substantial amount of $\mathrm{Cu}$. This cupriferous pseudobrookite has now been further investigated with a Jeol Superprobe JCXA 733 which has the necessary scanning equipment to allow one to see exactly what is being analysed in the pseudobrookite-hematite-rutile intergrowths.

\section{Analytical results}

The electron microprobe analyses were carried out with $15.0 \mathrm{kV}$ accelerating voltage and a sample current of $20.0 \mathrm{nA}$ using hematite, $\mathrm{TiO}_{2}$, $\mathrm{MgO}, \mathrm{Al}_{2} \mathrm{O}_{3}, \mathrm{Mn}, \mathrm{Cu}$ and $\mathrm{Cr}$ as standards $(\mathrm{Cr}$ was not determined in all the analyses). Total iron was divided between ferrous and ferric iron by the method suggested by Finger (1972). The detection limit for $\mathrm{Cu}$ is $0.01 \% \mathrm{CuO}$.

Pseudobrookite formed from previous titanomagnetite can be recognised by the presence of larger areas of hematite in the grains and frequently also by the presence of relic $\{111\}$ planes after ilmenite lamellae (fig. 1), whereas pseudobrookite formed from previous ilmenite results in grains consisting almost entirely of pseudobrookite containing only small blebs of hematite and rutile (fig. 2).

The analyses were all carried out on a sample taken seven metres above the lower contact of the approximately $18 \frac{1}{2} \mathrm{~m}$ thick flow from the upper series described by Jensen (1978, 1980, 1982). Table 1 shows four analyses from each of three different grains of pseudobrookite after ilmenite, and table 2 shows eight analyses of pseudobrookite after titanomagnetite.

The $\mathrm{Cu}$ content of the pseudobrookite can be seen to be highly variable, and there is a striking difference between pseudobrookite after titanomagnetite and pseudobrookite after ilmenite. Pseudobrookite after titanomagnetite contains

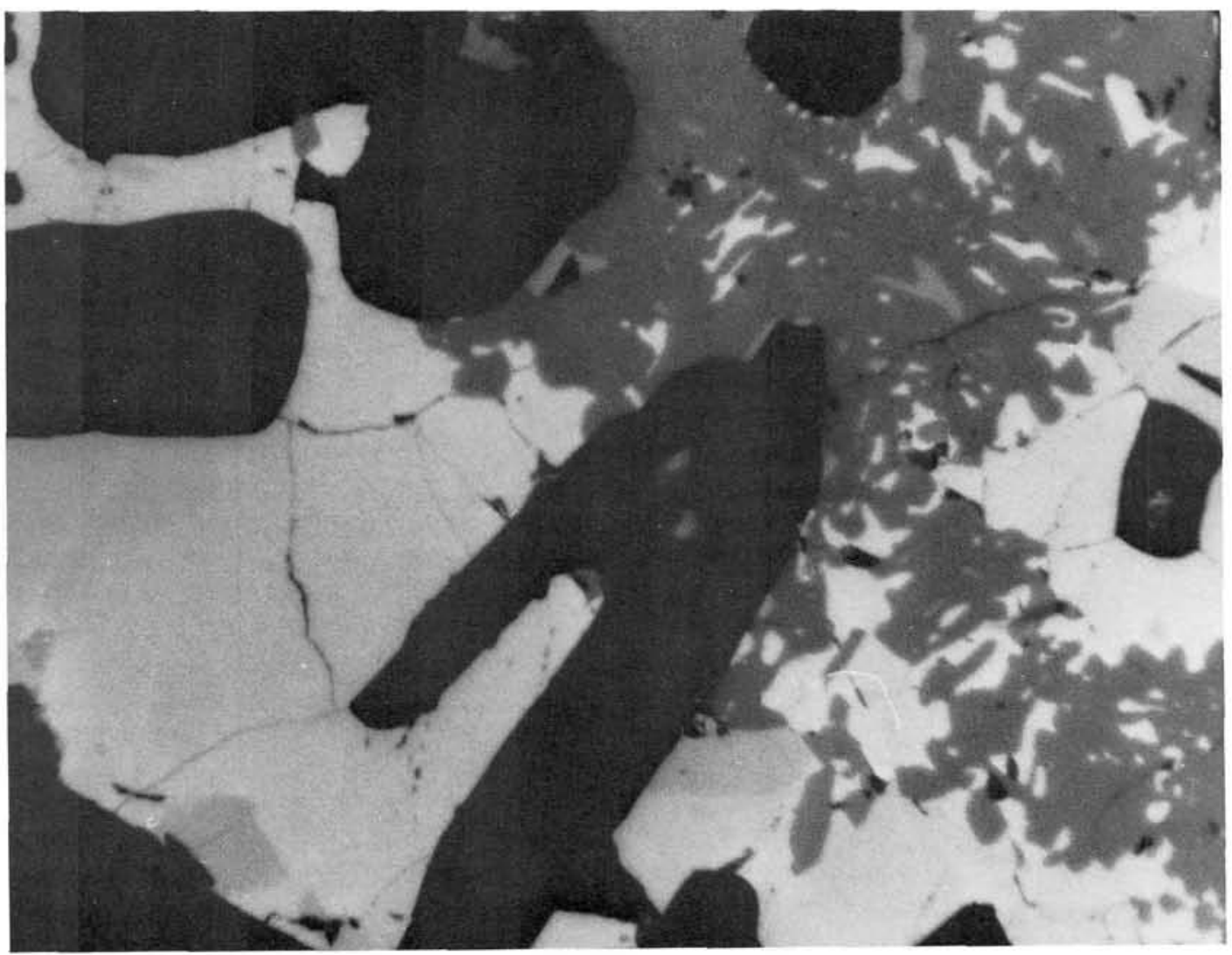

Fig, 1. Polariser only. $\times 1000$. Oil immersion. Pseudobrookite formed after titanomagnetite (dark grey), hematite in larger coherent areas and as small blebs in pseudobrookite (white), and rutile blebs in pseudobrookite (medium grey). 


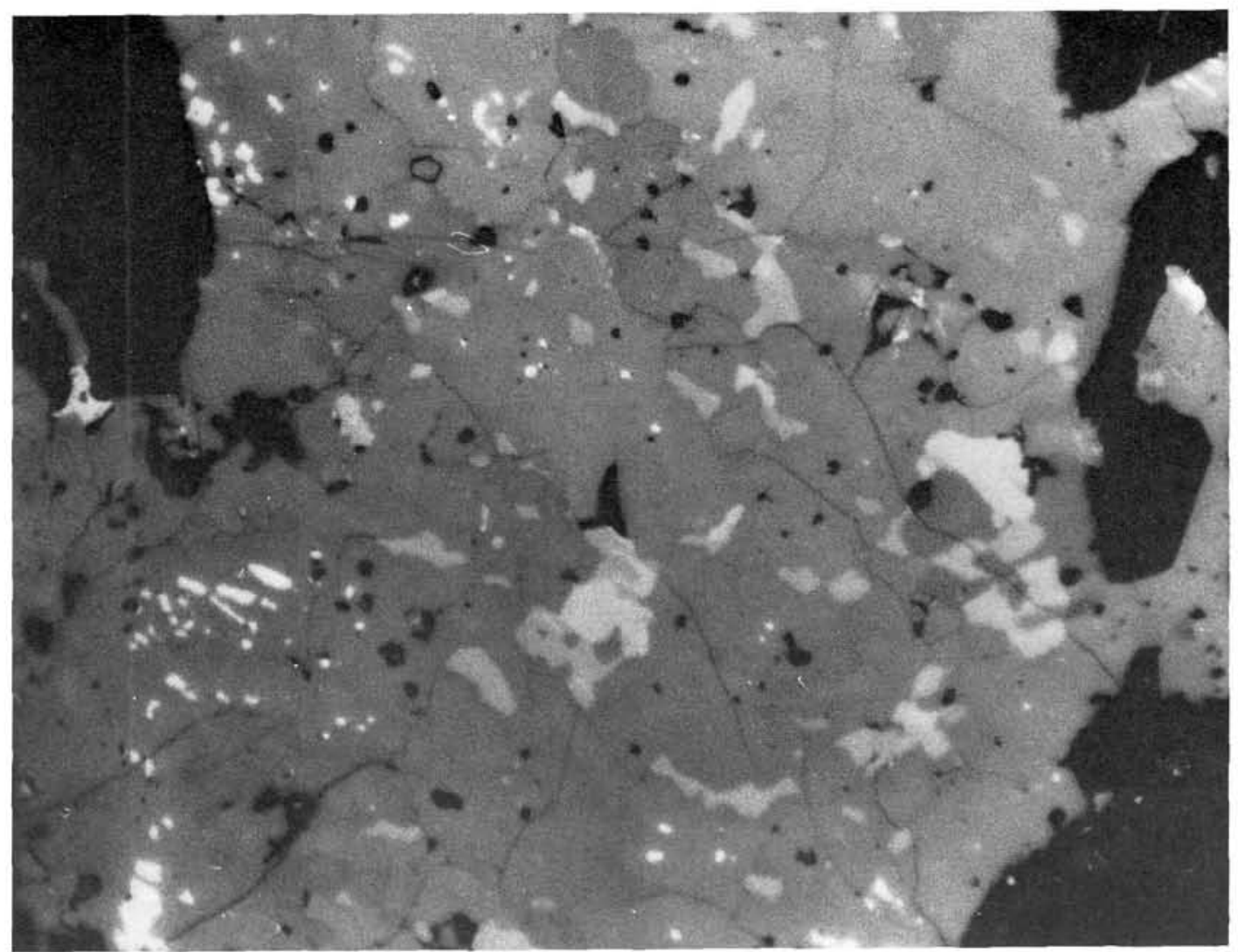

Fig. 2. Polariser only, $\times 1000$. Oil immersion. Pseudobrookite formed after ilmenite (dark grey) with small blebs of hematite (white) and rutile (medium grey).

only small, frequently not detectable, amounts of $\mathrm{Cu}$, whereas pseudobrookite after ilmenite contains between 1 and $3 \% \mathrm{CuO}$. The $\mathrm{Cu}$ content differs between grains but is rather constant within single grains.

The pseudobrookite in the Faeroe Islands basalt, whether developed from ilmenite or from titanomagnetite, is richer in $\mathrm{Ti}^{4+}$ than in the formula $\mathrm{Fe}_{2} \mathrm{TiO}_{5}$. The surplus $\mathrm{Ti}^{4+}$ is balanced by the presence of divalent ions such as $\mathrm{Mg}, \mathrm{Mn}, \mathrm{Fe}$ and $\mathrm{Cu} . \mathrm{Mg}$ and $\mathrm{Cu}$ dominate in pseudobrookite after ilmenite, and $\mathrm{Fe}$ and $\mathrm{Mg}$ dominate in pseudobrookite after titanomagnetite. The surplus of $\mathrm{Ti}^{4+}$ is considerably greater in pseudobrookite after titanomagnetite than in pseudobrookite after ilmenite. As $\mathrm{Fe}^{++}$is the dominant divalent ion in pseudobrookite after titanomagnetite, this means that this pseudobrookite is richer in $\mathrm{FeTi}_{2} \mathrm{O}_{5}$ than pseudobrookite after ilmenite. This is in contrast to the finding of Haggerty (1976, p. 55).
$\mathrm{Al}_{2} \mathrm{O}_{3}$ is considerably higher in pseudobrookite after titanomagnetite than in pseudobrookite after ilmenite. $\mathrm{MnO}$ is somewhat higher in pseudobrookite after ilmenite than in pseudobrookite after titanomagnetite.

Pseudobrookite is usually considered a solid solution series of the four end members $\mathrm{Fe}_{2} \mathrm{TiO}_{5}$, $\mathrm{FeTi}_{2} \mathrm{O}_{5}$ (ferropseudobrookite), $\mathrm{MgTi}_{2} \mathrm{O}_{5}$ (karrooite) and $\mathrm{Al}_{2} \mathrm{TiO}_{5}$ (tielite/tialite), but in the light of the analyses presented here it seems reasonable to include also a $\mathrm{Cu}$ compound. The writer believes that the $\mathrm{Cu}$ is present as $\mathrm{Cu}^{++}$, although a compound $\mathrm{CuTi}_{2} \mathrm{O}_{5}$ is not known while $\mathrm{Cu}_{2} \mathrm{Ti}_{2} \mathrm{O}_{5}$ has been synthesised.

The pseudobrookite is not homogeneous. Both pseudobrookite after ilmenite and pseudobrookite after titanomagnetite contain small blebs of hematite and rutile from less than $1 \mu \mathrm{m}$ to about $10 \mu \mathrm{m}$ in size, and pseudobrookite after titano- 
Table 1

Electron microprobe analyses of pseudobrookite after ilmenite.

\begin{tabular}{lrrrrrrrrrrrr}
\hline $\begin{array}{l}\text { Grain } \\
\text { Analysis } \\
\text { Weight \% }\end{array}$ & 1 & 1 & 1 & 1 & 2 & 2 & 2 & 2 & 3 & 3 & 3 & 3 \\
$\mathrm{MgO}$ & 1 & 2 & 3 & 4 & 5 & 6 & 7 & 8 & 9 & 10 & 11 & 12 \\
$\mathrm{Al}_{2} \mathrm{O}_{3}$ & & & & & & & & & & & & \\
$\mathrm{TiO}_{2}$ & 2.29 & 1.83 & 1.97 & 2.27 & 2.18 & 2.26 & 1.95 & 1.74 & 2.06 & 2.03 & 2.33 & 2.44 \\
$\mathrm{Cr}_{2} \mathrm{O}_{3}$ & 0.09 & 0.13 & 0.13 & 0.19 & 0.09 & 0.10 & 0.07 & 0.07 & 0.10 & 0.13 & 0.08 & 0.14 \\
$\mathrm{MnO}$ & 41.61 & 40.18 & 40.84 & 41.65 & 41.63 & 41.34 & 40.72 & 39.45 & 39.77 & 39.96 & 40.47 & 40.76 \\
$\mathrm{FeO}$ & & & & & & & & & 0.00 & 0.04 & 0.02 & 0.03 \\
$\mathrm{Fe}_{2} \mathrm{O}_{3}$ & 0.54 & 0.47 & 0.36 & 0.46 & 0.38 & 0.38 & 0.35 & 0.39 & 0.56 & 0.58 & 0.53 & 0.50 \\
$\mathrm{CuO}$ & 0.34 & 0.00 & 0.52 & 0.00 & 0.86 & 0.79 & 0.61 & 0.09 & 0.00 & 0.34 & 0.00 & 0.00 \\
& 52.35 & 54.45 & 53.66 & 51.73 & 52.81 & 52.68 & 53.59 & 56.31 & 55.76 & 55.62 & 54.82 & 54.85 \\
& 2.15 & 2.29 & 2.08 & 2.88 & 1.78 & 1.73 & 1.98 & 1.62 & 1.27 & 1.10 & 1.32 & 1.25 \\
\hline & 99.37 & 99.35 & 99.56 & 99.18 & 99.73 & 99.28 & 99.27 & 99.67 & 99.52 & 99.80 & 99.57 & 99.97
\end{tabular}

Number of cations on the bais of 3 cations and 5 oxygens

\begin{tabular}{|c|c|c|c|c|c|c|c|c|c|c|c|c|}
\hline $\mathrm{Ti}$ & 1.226 & 1.190 & 1.205 & 1.229 & 1.223 & 1.219 & 1.205 & 1.166 & 1.173 & 1.179 & 1.190 & 1.192 \\
\hline $\begin{array}{l}\mathrm{Fe}^{+++} \\
\mathrm{Al} \\
\mathrm{Cr}\end{array}$ & $\begin{array}{l}1.544 \\
0.004\end{array}$ & $\begin{array}{l}1.613 \\
0.006\end{array}$ & $\begin{array}{l}1.584 \\
0.006\end{array}$ & $\begin{array}{l}1.528 \\
0.009\end{array}$ & $\begin{array}{l}1.552 \\
0.004\end{array}$ & $\begin{array}{l}1.555 \\
0.005\end{array}$ & $\begin{array}{l}1.587 \\
0.003\end{array}$ & $\begin{array}{l}1.665 \\
0.003\end{array}$ & $\begin{array}{l}1.646 \\
0.005 \\
0.000\end{array}$ & $\begin{array}{l}1.633 \\
0.006 \\
0.001\end{array}$ & $\begin{array}{l}1.613 \\
0.004 \\
0.001\end{array}$ & $\begin{array}{l}1.606 \\
0.006 \\
0.001\end{array}$ \\
\hline$\Sigma M^{+++}$ & 1.548 & 1.619 & 1.590 & 1.537 & 1.556 & 1.560 & 1.590 & 1.668 & 1.651 & 1.640 & 1.618 & 1.613 \\
\hline $\begin{array}{l}\mathrm{Mg} \\
\mathrm{Mn} \\
\mathrm{Fe}^{++} \\
\mathrm{Cu}\end{array}$ & $\begin{array}{l}0.134 \\
0.018 \\
0.011 \\
0.063\end{array}$ & $\begin{array}{l}0.107 \\
0.016 \\
0.000 \\
0.068\end{array}$ & $\begin{array}{l}0.115 \\
0.012 \\
0.017 \\
0.061\end{array}$ & $\begin{array}{l}0.133 \\
0.015 \\
0.000 \\
0.086\end{array}$ & $\begin{array}{l}0.127 \\
0.013 \\
0.028 \\
0.052\end{array}$ & $\begin{array}{l}0.132 \\
0.013 \\
0.026 \\
0.051\end{array}$ & $\begin{array}{l}0.114 \\
0.012 \\
0.020 \\
0.059\end{array}$ & $\begin{array}{l}0.102 \\
0.013 \\
0.003 \\
0.048\end{array}$ & $\begin{array}{l}0.121 \\
0.018 \\
0.000 \\
0.038\end{array}$ & $\begin{array}{l}0.119 \\
0.019 \\
0.011 \\
0.033\end{array}$ & $\begin{array}{l}0.136 \\
0.017 \\
0.000 \\
0.039\end{array}$ & $\begin{array}{l}0.141 \\
0.017 \\
0.000 \\
0.037\end{array}$ \\
\hline$\Sigma \mathrm{M}^{++}$ & 0.226 & 0.191 & 0.205 & 0.234 & 0.220 & 0.222 & 0.205 & 0.166 & 0.177 & 0.182 & 0.192 & 0.195 \\
\hline
\end{tabular}

magnetite is intergrown furthermore with larger coherent areas of hematite (figs 1,2).

Table 3 shows three analyses of hematite blebs from each of the three pseudobrookite grains from table 1 . It is seen that these hematite blebs are even richer in $\mathrm{Cu}$ than the pseudobrookite in

Table 2

Electron microprobe analyses of pseudobrookite after titanomagnetite.

\begin{tabular}{|c|c|c|c|c|c|c|c|c|}
\hline $\begin{array}{l}\text { Analysis } \\
\text { Weight \% }\end{array}$ & 13 & 14 & 15 & 16 & 17 & 18 & 19 & 20 \\
\hline \multicolumn{9}{|l|}{ Weight \% } \\
\hline $\mathrm{MgO}$ & 2.52 & 2.04 & 2.39 & 2.42 & 2.07 & 1.50 & 1.24 & 1.14 \\
\hline $\mathrm{Al}_{2} \mathrm{O}_{3}$ & 1.06 & 1.05 & 1.03 & 1.07 & 1.35 & 0.96 & 0.78 & 0.80 \\
\hline $\mathrm{TiO}_{2}$ & 50.51 & 45.19 & 46.72 & 46.46 & 41.39 & 43.74 & 42.70 & 41.34 \\
\hline $\mathrm{Cr}_{2} \mathrm{O}_{3}$ & & & & & 0.11 & 0.04 & 0.08 & 0.08 \\
\hline $\mathrm{MnO}$ & 0.27 & 0.21 & 0.22 & 0.31 & 0.27 & 0.33 & 0.30 & 0.28 \\
\hline $\mathrm{FeO}$ & 9.60 & 6.07 & 6.72 & 6.27 & 2.43 & 5.59 & 5.32 & 4.32 \\
\hline $\mathrm{Fe}_{2} \mathrm{O}_{3}$ & 35.51 & 44.92 & 42.01 & 42.72 & 51.73 & 47.04 & 49.23 & 51.44 \\
\hline \multirow[t]{2}{*}{$\mathrm{CuO}$} & $<0.01$ & $<0.01$ & 0.05 & $<0.01$ & 0.01 & $<0.01$ & $<0.01$ & 0.01 \\
\hline & 99.47 & 99.48 & 99.14 & 99.25 & 99.36 & 99.20 & 99.65 & 99.41 \\
\hline \multicolumn{9}{|c|}{ Number of cations on the basis of 3 cations and 5 oxygens } \\
\hline $\mathrm{Ti}$ & 1.462 & 1.319 & 1.362 & 1.353 & 1.211 & 1.287 & 1.256 & 1.221 \\
\hline $\mathrm{Fe}^{+++}$ & 1.028 & 1.312 & 1.226 & 1.245 & 1.515 & 1.385 & 1.449 & 1.521 \\
\hline Al & 0.048 & 0.048 & 0.048 & 0.049 & 0.062 & 0.044 & 0.036 & 0.037 \\
\hline $\mathrm{Cr}$ & & & & & 0.003 & 0.001 & 0.003 & 0.002 \\
\hline$\Sigma \mathrm{M}^{+++}$ & 1.076 & 1.360 & 1.274 & 1.294 & 1.580 & 1.430 & 1.488 & 1.560 \\
\hline $\mathrm{Mg}$ & 0.144 & 0.118 & 0.138 & 0.140 & 0.120 & 0.087 & 0.072 & 0.067 \\
\hline $\mathrm{Mn}$ & 0.009 & 0.007 & 0.007 & 0.010 & 0.009 & 0.011 & 0.010 & 0.009 \\
\hline $\mathrm{Fe}^{++}$ & 0.309 & 0.197 & 0.218 & 0.203 & 0.079 & 0.183 & 0.174 & 0.142 \\
\hline $\mathrm{Cu}$ & 0.000 & 0.000 & 0.002 & 0.000 & 0.000 & 0.000 & 0.000 & 0.000 \\
\hline$\Sigma \mathrm{M}^{++}$ & 0.462 & 0.322 & 0.365 & 0.353 & 0.208 & 0.281 & 0.256 & 0.218 \\
\hline
\end{tabular}


Table 3

Electron microprobe analyses of hematite blebs in pseudobrookite after ilmenite.

\begin{tabular}{|c|c|c|c|c|c|c|c|c|c|}
\hline Grain & 1 & 1 & 1 & 2 & 2 & 2 & 3 & 3 & 3 \\
\hline $\begin{array}{l}\text { Analysis } \\
\text { Weight } \%\end{array}$ & \multicolumn{5}{|c|}{ Weight $\%$} & 26 & 27 & 28 & 29 \\
\hline $\mathrm{MgO}$ & 0.86 & 0.75 & 0.84 & 1.05 & 1.08 & 1.12 & 0.91 & 0.90 & 1.01 \\
\hline $\mathrm{Al}_{2} \mathrm{O}_{3}$ & 0.33 & 0.16 & 0.04 & 0.06 & 0.08 & 0.06 & 0.09 & 0.06 & 0.08 \\
\hline $\mathrm{TiO}_{2}$ & 9.25 & 9.41 & 12.17 & 7.59 & 9.40 & 13.59 & 12.50 & 8.56 & 13.35 \\
\hline $\mathrm{Cr}_{2} \mathrm{O}_{3}$ & & & & & & & 0.05 & 0.05 & 0.08 \\
\hline $\mathrm{MnO}$ & 0.76 & 1.27 & 0.72 & 0.83 & 0.56 & 0.44 & 0.55 & 0.72 & 0.60 \\
\hline $\mathrm{FeO}$ & 3.13 & 0.99 & 5.12 & 1.45 & 3.26 & 7.72 & 7.73 & 3.90 & 8.43 \\
\hline $\mathrm{Fe}_{2} \mathrm{O}_{3}$ & 83.33 & 80.93 & 76.30 & 85.49 & 83.27 & 74.25 & 77.25 & 84.58 & 74.97 \\
\hline \multirow[t]{2}{*}{$\mathrm{CuO}$} & 3.24 & 5.48 & 4.01 & 3.00 & 2.87 & 2.37 & 1.33 & 1.62 & 1.31 \\
\hline & 100.90 & 98.99 & 99.20 & 99.47 & 100.52 & 99.55 & 100.41 & 100.39 & 99.83 \\
\hline \multicolumn{10}{|c|}{ Number of cations on the bais of 2 cations and 3 oxygens } \\
\hline $\mathrm{Ti}$ & 0.181 & 0.188 & 0.242 & 0.151 & 0.184 & 0.267 & 0.244 & 0.168 & 0.262 \\
\hline $\mathrm{Fe}^{+++}$ & 1.628 & 1.617 & 1.515 & 1.696 & 1.632 & 1.462 & 1.510 & 1.661 & 1.472 \\
\hline $\mathrm{Al}$ & 0.010 & 0.005 & 0.001 & 0.002 & 0.002 & 0.002 & 0.003 & 0.002 & 0.002 \\
\hline $\mathrm{Cr}$ & & & & & & & 0.001 & 0.001 & 0.002 \\
\hline$\Sigma \mathrm{M}^{+++}$ & 1.638 & 1.622 & 1.516 & 1.698 & 1.634 & 1.464 & 1.514 & 1.664 & 1.476 \\
\hline $\mathrm{Mg}$ & 0.033 & 0.030 & 0.033 & 0.041 & 0.042 & 0.044 & 0.035 & 0.035 & 0.039 \\
\hline Mn & 0.017 & 0.029 & 0.016 & 0.018 & 0.012 & 0.010 & 0.012 & 0.016 & 0.013 \\
\hline $\mathrm{Fe}^{++}$ & 0.068 & 0.022 & 0.113 & 0.032 & 0.071 & 0.169 & 0.168 & 0.085 & 0.184 \\
\hline $\mathrm{Cu}$ & 0.063 & 0.110 & 0.080 & 0.060 & 0.056 & 0.047 & 0.026 & 0.032 & 0.026 \\
\hline$\Sigma \mathbf{M}^{++}$ & 0.181 & 0.191 & 0.242 & 0.151 & 0.181 & 0.270 & 0.241 & 0.168 & 0.262 \\
\hline
\end{tabular}

which they occur. The writer believes that here also the $\mathrm{Cu}$ is present as $\mathrm{Cu}^{++}$. The hematite blebs are also richer in $\mathrm{FeO}$ and $\mathrm{MnO}$ (and prob- ably $\mathrm{Cr}_{2} \mathrm{O}_{3}$ ), but poorer in $\mathrm{MgO}$ than the pseudobrookite in which they occur.

Table 4 shows eight analyses of hematite in

Table 4

Electron microprobe analyses of hematite in pseudobrookit after titanomagnetite.

\begin{tabular}{|c|c|c|c|c|c|c|c|c|}
\hline Analysis & 30 & 31 & 32 & 33 & 34 & 35 & 36 & 37 \\
\hline \multicolumn{9}{|l|}{ Weight \% } \\
\hline $\mathrm{MgO}$ & 0.37 & 0.38 & 0.42 & 0.32 & 1.35 & 1.47 & 1.02 & 1.11 \\
\hline $\mathrm{Al}_{2} \mathrm{O}_{3}$ & 0.52 & 0.56 & 0.62 & 0.69 & 0.74 & 0.65 & 1.06 & 0.91 \\
\hline $\mathrm{TiO}_{2}$ & 13.38 & 13.21 & 13.24 & 13.54 & 15.76 & 16.30 & 13.63 & 14.81 \\
\hline $\mathrm{Cr}_{2} \dot{\mathrm{O}}_{3}$ & 0.33 & 0.29 & 0.26 & 0.22 & 0.33 & 0.17 & 0.13 & 0.12 \\
\hline $\mathrm{MnO}$ & 0.76 & 0.24 & 0.15 & 0.22 & 0.42 & 0.44 & 0.27 & 0.43 \\
\hline $\mathrm{FeO}$ & 10.75 & 10.82 & 10.92 & 11.39 & 11.51 & 11.78 & 10.22 & 10.88 \\
\hline $\mathrm{Fe}_{2} \mathrm{O}_{3}$ & 74.07 & 73.64 & 73.49 & 72.94 & 69.55 & 68.65 & 73.59 & 70.85 \\
\hline \multirow[t]{2}{*}{$\mathrm{CuO}$} & $<0.01$ & $<0.01$ & 0.02 & $<0.01$ & 0.02 & 0.04 & 0.08 & 0.03 \\
\hline & 100.18 & 99.14 & 99.12 & 99.32 & 99.68 & 99.50 & 100.00 & 99.14 \\
\hline \multicolumn{9}{|c|}{ Number of cations on the basis of 2 cations and 3 oxygens } \\
\hline $\mathrm{Ti}$ & 0.262 & 0.261 & 0.262 & 0.267 & 0.307 & 0.317 & 0.265 & 0.290 \\
\hline $\mathrm{Fe}^{+++}$ & 1.451 & 1.457 & 1.454 & 1.440 & 1.354 & 1.338 & 1.432 & 1.389 \\
\hline Al & 0.016 & 0.017 & 0.019 & 0.021 & 0.023 & 0.020 & 0.032 & 0.028 \\
\hline $\mathrm{Cr}$ & 0.007 & 0.006 & 0.005 & 0.005 & 0.007 & 0.004 & 0.003 & 0.003 \\
\hline$\Sigma \mathbf{M}^{+++}$ & 1.474 & 1.480 & 1.478 & 1.466 & 1.384 & 1.362 & 1.467 & 1.420 \\
\hline $\mathrm{Mg}$ & 0.014 & 0.015 & 0.016 & 0.012 & 0.052 & 0.057 & 0.039 & 0.043 \\
\hline $\mathrm{Mn}$ & 0.017 & 0.005 & 0.003 & 0.005 & 0.009 & 0.010 & 0.006 & 0.009 \\
\hline $\mathrm{Fe}^{++}$ & 0.234 & 0.238 & 0.240 & 0.250 & 0.249 & 0.255 & 0.221 & 0.237 \\
\hline $\mathrm{Cu}$ & 0.000 & 0.000 & 0.000 & 0.000 & 0.000 & 0.001 & 0.002 & 0.001 \\
\hline$\Sigma \mathbf{M}^{++}$ & 0.265 & 0.258 & 0.259 & 0.267 & 0.310 & 0.323 & 0.268 & 0.290 \\
\hline
\end{tabular}


Table 5

Electron microprobe analyses of rutile blebs in pseudobrookite, the first four after ilmenite, the last four after titanomagnetite.

\begin{tabular}{lrrrrrrrr}
\hline $\begin{array}{l}\text { Analysis } \\
\text { Weight \% }\end{array}$ & 38 & 39 & 40 & 41 & 42 & 43 & 44 & 45 \\
$\mathrm{MgO}$ & & & & & & & \\
$\mathrm{Al}_{2} \mathrm{O}_{3}$ & 0.00 & 0.00 & 0.01 & 0.00 & 0.03 & 0.04 & 0.03 & 0.00 \\
$\mathrm{TiO}_{2}$ & 0.00 & 0.00 & 0.00 & 0.00 & 0.02 & 0.02 & 0.01 & 0.02 \\
$\mathrm{MnO}_{\mathrm{FeO}}$ & 97.46 & 99.33 & 97.75 & 98.55 & 97.32 & 95.21 & 96.07 & 96.44 \\
$\mathrm{Fe}_{2} \mathrm{O}_{3}$ & 0.05 & 0.03 & 0.07 & 0.08 & 0.01 & 0.04 & 0.00 & 0.01 \\
$\mathrm{CuO}$ & 0.00 & 0.00 & 0.00 & 0.00 & 0.00 & 0.00 & 0.00 & 0.00 \\
& 1.48 & 0.98 & 1.36 & 1.40 & 2.82 & 4.04 & 3.08 & 3.31 \\
& 0.14 & 0.05 & 0.05 & $<0.01$ & $<0.01$ & 0.01 & $<0.01$ & 0.02 \\
\hline & 99.13 & 100.39 & 99.24 & 100.03 & 100.20 & 99.36 & 99.19 & 99.80 \\
\hline
\end{tabular}

pseudobrookite after titanomagnetite; the first four are from blebs inside pseudobrookite, and the last four are from larger coherent areas of hematite. It is seen that the hematite blebs do not contain more $\mathrm{Cu}$ than the pseudobrookite, whereas hematite in larger coherent areas appears to be very slightly richer in $\mathrm{Cu}$ than the pseudobrookite. The hematite blebs as well as the hematite in larger coherent areas are richer in $\mathrm{FeO}$ (and probably in $\mathrm{MnO}$ and $\mathrm{Cr}_{2} \mathrm{O}_{3}$ ), but poorer in $\mathrm{MgO}$ and $\mathrm{Al}_{2} \mathrm{O}_{3}$, than the pseudobrookite. However, the differences in $\mathrm{MgO}$ and $\mathrm{Al}_{2} \mathrm{O}_{3}$

Table 6

Average of 8 electron microprobe analyses of ilmenite and average of 13 partial electron microprobe analyses of titanomagnetite.

\begin{tabular}{|c|c|c|}
\hline & Ilmenite & Titanomagnetite \\
\hline \multicolumn{3}{|c|}{ Weight \% } \\
\hline $\mathrm{MgO}$ & $1.90 \pm 0.10$ & $1.41 \pm 0.32$ \\
\hline $\mathrm{Al}_{2} \mathrm{O}_{3}$ & $0.08 \pm 0.03$ & $0.07 \pm 0.02$ \\
\hline $\mathrm{TiO}_{2}$ & $50.88 \pm 0.36$ & \\
\hline $\mathrm{MnO}$ & $0.32 \pm 0.03$ & $0.46 \pm 0.08$ \\
\hline $\mathrm{FeO}$ & $41.97 \pm 0.50$ & \\
\hline $\mathrm{Fe}_{2} \mathrm{O}_{3}$ & $4.67 \pm 0.94$ & \\
\hline \multirow[t]{2}{*}{$\mathrm{CuO}$} & $0.03 \pm 0.03$ & $0.01 \pm 0.01$ \\
\hline & $99.85 \pm 0.35$ & \\
\hline \multicolumn{3}{|c|}{ Number of cations on the basis of 2 cations and 3 oxygens } \\
\hline $\mathrm{Ti}$ & $0.956 \pm 0.008$ & \\
\hline $\mathrm{Fe}^{+++}$ & $0.088 \pm 0.017$ & \\
\hline Al & $0.002 \pm 0.001$ & \\
\hline$\Sigma \mathbf{M}^{+++}$ & $0.090 \pm 0.017$ & \\
\hline Mg & $0.071 \pm 0.003$ & \\
\hline $\mathrm{Mn}$ & $0.007 \pm 0.001$ & \\
\hline $\mathrm{Fe}^{++}$ & $0.877 \pm 0.012$ & \\
\hline $\mathrm{Cu}$ & $0.000 \pm 0.001$ & \\
\hline$\Sigma \mathbf{M}^{++}$ & $0.954 \pm 0.009$ & \\
\hline
\end{tabular}

are not as prominent for the hematite in larger coherent areas as for the hematite blebs.

Table 5 shows four analyses of rutile blebs in pseudobrookite after ilmenite, and four of rutile blebs in pseudobrookite after titanomagnetite. Apart from a varying amount of $\mathrm{Fe}_{2} \mathrm{O}_{3}$, the rutile blebs are practically pure $\mathrm{TiO}_{2}$. Blebs in pseudobrookite after titanomagnetite are free of $\mathrm{Cu}$, whereas blebs in pseudobrookite after ilmenite appear to contain just a trifle $\mathrm{Cu}$.

The oxidation stages of the sample on which the pseudobrookite analyses were carried out vary between $\mathrm{C} 4$ and $\mathrm{C} 7$ for the cubic phases and between R3 and R7 for the rhombohedral phases. Accordingly the composition of the original ilmenite and the original titanomagnetite could not be obtained from this sample.

In order to see whether the difference in $\mathrm{Cu}$ content between pseudobrookite after ilmenite and pseudobrookite after titanomagnetite could be inherited from the original ilmenite and titanomagnetite, the composition of the latter were investigated in a sample taken three metres lower in the same flow. In this sample the oxidation stages for the cubic phases vary between $\mathrm{C} 2$ and $\mathrm{C} 3$ and the oxidation stage of the rhombohedral phase is invariably R1. This attempt to establish the composition of the original ilmenite and titanomagnetite was however only successful with ilmenite (table 6), as the relations between $\mathrm{Ti}, \mathrm{Fe}^{+++}$and $\mathrm{Fe}^{++}$could not be established for the titanomagnetite because of maghemitisation. Hence only partial electon microprobe analyses of this titanomagnetite are presented in table 6 . It can be seen, however, that the amounts of $\mathrm{Cu}$ in both ilmenite and titanomagnetite are very small.

Table 7 presents whole rock analyses of the samples on which the pseudobrookite analyses 
Table 7

Chemical analyses of rock samples.

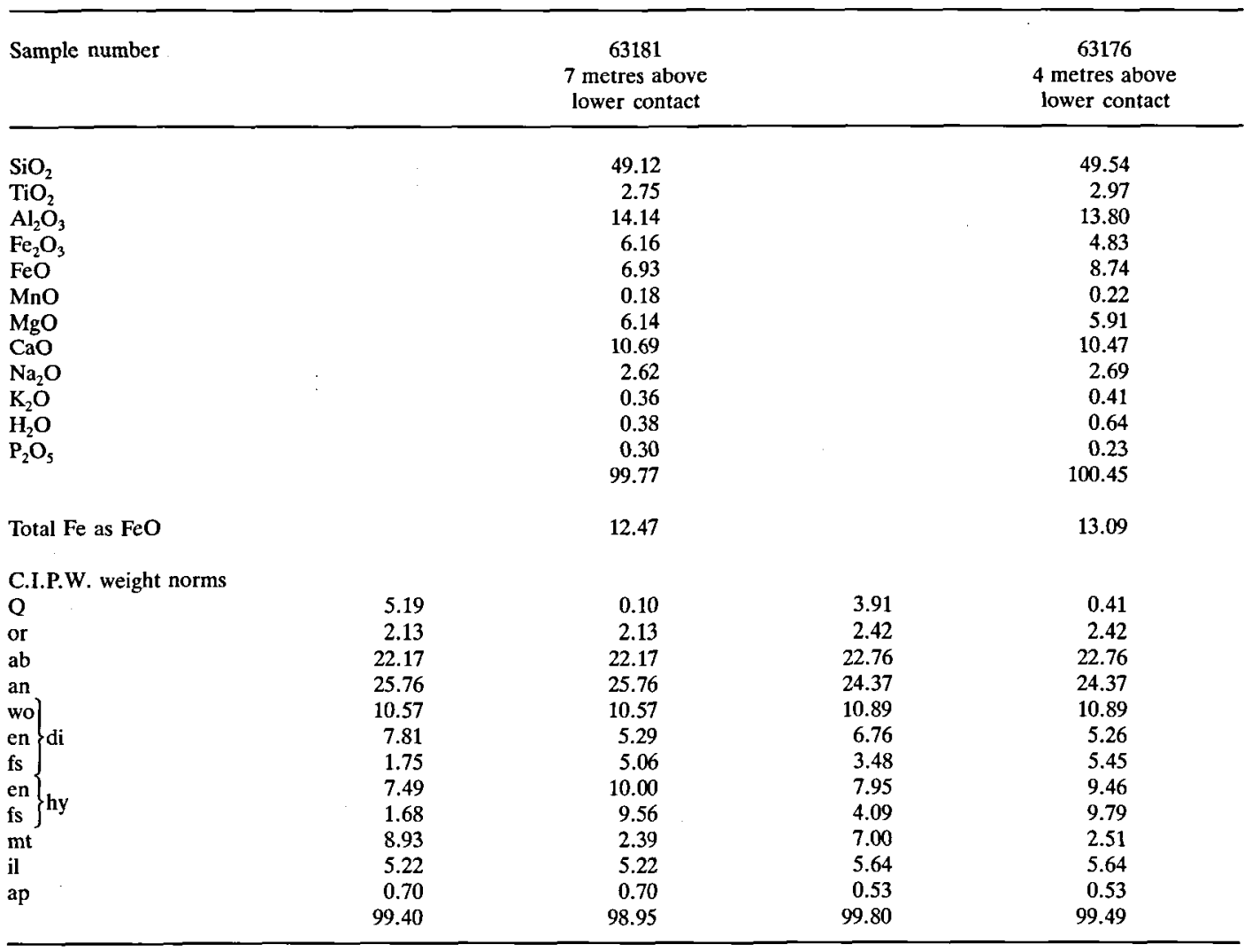

were carried out. The rock samples were analysed in the laboratory of the Geological Survey of Greenland by $\mathrm{Ib}$ Sørensen. $\mathrm{H}_{2} \mathrm{O}^{+}$was determined by the Penfield method and $\mathrm{Fe}^{++}$by wet chemistry. $\mathrm{Mg}$ was determined by complexometric titration, $\mathrm{Na}$ by flame photometry, and the remaining elements were analysed by XRF on glass discs. CIPW weight norms were calculated with the ration $\mathrm{Fe}_{2} \mathrm{O}_{3} / \mathrm{FeO}$ found by analysis (first column) as well as with this ratio adjusted to 0.15 (second column).

\section{Deviations from the formula $\mathrm{Fe}_{2} \mathrm{TiO}_{5}$}

The transformation of ideal ilmenite $\mathrm{FeTiO}_{3}$ to ideal pseudobrookite $\mathrm{Fe}_{2} \mathrm{TiO}_{5}$ results in loss of $19.30 \% \mathrm{TiO}_{2}$ (by weight), oxidation of $47.35 \%$ $\mathrm{FeO}$ to $52.62 \% \mathrm{Fe}_{2} \mathrm{O}_{3}$, and addition of a further $14.03 \% \mathrm{Fe}_{2} \mathrm{O}_{3}$.
Comparing the analyses of ilmenite (table 6) with those of pseudobrookite after ilmenite (table 1 ), we see that the transformation of ilmenite to pseudobrookite in the Faeroe Islands basalt has resulted in the loss of only $10 \% \mathrm{TiO}_{2}$, and addition of only $3 \% \quad \mathrm{Fe}_{2} \mathrm{O}_{3}$. The transformation, however, has also resulted in the addition of $1-2 \% \mathrm{CuO}$, whereas the values for $\mathrm{MgO}, \mathrm{Al}_{2} \mathrm{O}_{3}$ and $\mathrm{MnO}$ are very similar, but might indicate a slight increase. Thus it is seen that in the transformation of ilmenite to pseudobrookite in the Faeroe Islands basalt only about half of the expected amount of $\mathrm{Ti}$ has been lost, and a correspondingly smaller amount of $\mathrm{Fe}$ has been added.

The transformation of titanomagnetite of the composition $\frac{1}{2} \mathrm{Fe}_{3} \mathrm{O}_{4} \cdot \frac{1}{2} \mathrm{Fe}_{2} \mathrm{TiO}_{4}$ to ideal pseudobrookite $\mathrm{Fe}_{2} \mathrm{TiO}_{5}$ results in loss of $18.96 \% \mathrm{FeO}$, oxidation of the remaining $28.40 \% \mathrm{FeO}$ to $31.56 \% \mathrm{Fe}_{2} \mathrm{O}_{3}$, and addition of $15.80 \% \mathrm{TiO}_{2}$. The transformation of titanomagnetite of the com- 
position $2 / 10 \mathrm{Fe}_{3} \mathrm{O}_{4} \cdot 8 / 10 \mathrm{Fe}_{2} \mathrm{TiO}_{4}$ to ideal pseudobrookite $\mathrm{Fe}_{2} \mathrm{TiO}_{5}$ results in loss of $10.21 \% \mathrm{FeO}$, oxidation of the remaining $47.22 \% \mathrm{FeO}$ to $52.47 \% \mathrm{Fe}_{2} \mathrm{O}_{3}$, and addition of $4.96 \% \mathrm{TiO}_{2}$.

The transformation of titanomagnetite of the composition $\frac{1}{2} \mathrm{Fe}_{3} \mathrm{O}_{4} \cdot \frac{1}{2} \mathrm{Fe}_{2} \mathrm{TiO}_{4}$ to the pseudobrookite compostion given by the analyses of pseudobrookite after titanomagnetite (table 2 ) is accomplished by addition of $27 \% \mathrm{TiO}_{2}$ and a correspondingly large loss of $\mathrm{FeO}(32 \%)$. Thus it is seen that if the titanomagnetite in the Faeroe Islands basalt had the composition $\frac{1}{2} \mathrm{Fe}_{3} \mathrm{O}_{4} \cdot \frac{1}{2} \mathrm{Fe}_{2}$ $\mathrm{TiO}_{4}$, about twice as much $\mathrm{TiO}_{2}$ as expected has been added, and a correspondingly larger amount of $\mathrm{FeO}$ has been lost. If the original titanomagnetite in the Faeroe Islands basalt was richer in $\mathrm{Fe}_{2} \mathrm{TiO}_{4}$ than $\frac{1}{2} \mathrm{Fe}_{3} \mathrm{O}_{4} \cdot \frac{1}{2} \mathrm{Fe}_{2} \mathrm{TiO}_{4}$, the discrepancy is even greater. Thus if the original titanomagnetite had the composition $2 / 10 \mathrm{Fe}_{3}$ $\mathrm{O}_{4} \cdot 8 / 10 \mathrm{Fe}_{2} \mathrm{TiO}_{4}$, more than three times the expected amount of Ti has been added, and correspondingly more $\mathrm{FeO}$ has been lost.

Whereas ilmenite is more or less completely altered to pseudobrookite, the formation of pseudobrookite from titanomagnetite is always accompanied by the formation of larger areas of hematite. The $\mathrm{FeO}$ lost in the titanomagnetite $\rightarrow$ pseudobrookite reaction was probably mostly used to form these hematite areas.

When the partial electron microprobe analysis of titanomagnetite (table 6 ) is compared with the analyses of pseudobrookite after titanomagnetite (table 2), it is seen that the transformation of titanomagnetite to pseudobrookite has resulted in addition of $\mathrm{Al}_{2} \mathrm{O}_{3}$, and to some extent also in addition of $\mathrm{MgO}$ and loss of $\mathrm{MnO}$.

\section{Conclusions}

It has been shown that besides the four end members $\mathrm{Fe}_{2} \mathrm{TiO}_{5}, \mathrm{FeTi}_{2} \mathrm{O}_{5}, \mathrm{MgTi}_{2} \mathrm{O}_{5}$ and $\mathrm{Al}_{2} \mathrm{TiO}_{5}$, a $\mathrm{Cu}$ compound is needed to describe the pseudobrookite formed from previous ilmenite in a Faeroe Islands basalt.

The pseudobrookites here, whether formed after ilmenite or after titanomagnetite, are considerably richer in $\mathrm{Ti}$ than in the formula $\mathrm{Fe}_{2} \mathrm{TiO}_{5}$. The enrichment in Ti is balanced by divalent ions such as $\mathrm{Mg}, \mathrm{Fe}, \mathrm{Mn}$ and $\mathrm{Cu}$.

The Fe-Ti exchange required by pseudobroo- kite-forming reactions is less than expected in pseudobrookite after ilmenite, and greater than expected in pseudobrookite after titanomagnetite. Pseudobrookite after titanomagnetite is somewhat richer in Ti than pseudobrookite after ilmenite, which contrasts with the pseudobrookite in a basalt from Oregon (Haggerty 1976). Furthermore, contrary to the finding of Haggerty (1976), pseudobrookite after ilmenite in the Faeroe Islands basalt has less $\mathrm{FeTi}_{2} \mathrm{O}_{5}$ than pseudobrookite after titanomagnetite.

Pseudobrookite after ilmenite is richer in $\mathrm{Cu}$ and $\mathrm{Mn}$ (and total $\mathrm{Fe}$ ) and poorer in $\mathrm{Al}$ (and $\mathrm{Cr}$ ) than pseudobrookite after titanomagnetite. In the formation of pseudobrookite from titanomagnetite $\mathrm{Fe}$ is lost, whereas the formation of pseudobrookite from ilmenite is accompanied by addition of $\mathrm{Fe}$, and the only explanation that can be offered for the difference in $\mathrm{Cu}$ content between the pseudobrookites is that $\mathrm{Cu}$ (and $\mathrm{Mn}$ ) follows Fe.

The high concentration of $\mathrm{Cu}$ in the hematite blebs in pseudobrookite after ilmenite is considered evidence for the blebs not being relics, but the result of incomplete formation of pseudobrookite, because of local lack of Ti in the hematite blebs and local lack of $\mathrm{Fe}$ in the rutile blebs.

Acknowledgements. The Jeol Superprobe on which the analyses were carried out was bought with funds from the Danish Natural Science Research Council, and is run under the supervision of $\mathbf{J}$. Rønsbo, Institute of Mineralogy, University of Copenhagen, whose assistance with the analyses is greatly appreciated. Thanks are due to T.C.R. Pulvertaft for kindly improving the English of the manuscript.

\section{Dansk sammendrag}

I et tidligere arbejde (Jensen 1982) er det blevet påvist at de oxiderede Fe-Ti-oxider i Færøbasalterne, repræsenterede af pseudobrookit-hæmatit-rutil sammenvoksninger kan indeholde op til $2.4 \% \mathrm{Cu}, \mathrm{og}$ at kobberet fortrinsvis sidder $\mathrm{i}$ pseudobrookit.

Denne kobberholdige pseudobrookit er nu blevet nærmere undersøgt ved hjælp af den nyanskaffede Jeol JCXA 733 mikrosonde, hvis gode scanning udstyr har gjort det muligt præcist at afgøre, hvilken fase $\mathrm{i}$ de tætte pseudobrookit-hamatit-rutil sammenvoksninger der analyseres.

Pseudobrookit der er opstået ved oxidation af oprindelige ilmenitkorn består næsten udelukkende af pseudobrookit, dog med en del 1-10 $\mu \mathrm{m}$ store indeslutninger af hxmatit og af rutil, medens pseudobrookit der er opstået ved oxidation af oprindelige titanomagnetitkorn kun delvis udgøres af pseudobrookit (med 1-10 $\mu \mathrm{m}$ store indeslutninger af hæmatit og af rutil), 
idet der tillige er store sammenhængende partier af hæmatit. Pseudobrookiten kan som regel ses fortrinsvis at være opstảet hvor der $\mathrm{i}$ den oprindelige titanomagnetit har været ilmenitlameller efter $\{111\}$.

Pseudobrookiten i Færøbasalterne er, uanset om den er dannet af oprindelig ilmenit eller oprindelig titanomagnetit, betydeligt rigere på $\mathrm{Ti}$ end svarende til formlen $\mathrm{Fe}_{2} \mathrm{TiO}_{5}$. Den overskydende Ti modsvares af tilstedeværelsen af divalente ioner såsom $\mathrm{Mg}, \mathrm{Fe}, \mathrm{Mn}$ og $\mathrm{Cu} . \mathrm{Mg}$ og $\mathrm{Cu}$ dominerer i pseudobrookit efter ilmenit, og Fe og Mg dominerer i pseudobrookit efter titanomagnetit. Pseudobrookit efter titanomagnetit indeholder mere Al end pseudobrookit efter ilmenit.

Udvekslingen af Ti- Fe ved pseudobrookitdannelsen er mindre end forventet for pseudobrookit dannet af oprindelig ilmenit og større end forventet for pseudobrookit dannet af oprindelig titanomagnetit, og pseudobrookit efter titanomagnetit er noget rigere på Ti end pseudobrookit efter ilmenit. Endvidere er pseudobrookit efter ilmenit i Færøbasalterne fattigere på $\mathrm{FeTi}_{2} \mathrm{O}_{5}$ (ferropseudobrookit) end pseudobrookit efter titanomagnetit, hvilket er i modsætning til de pseudobrookitanalyser der anføres af Haggerty (1976).

Pseudobrookit efter titanomagnetit indeholder næsten ikke $\mathrm{Cu}$ (tabel 2), medens pseudobrookit efter ilmenit har et indhold varierende fra godt $1 \% \mathrm{CuO}$ til knap $3 \% \mathrm{CuO}$ (tabel 1). De små indeslutninger af hæmatit i pseudobrookit efter ilmenit er endnu rigere på $\mathrm{Cu}$ end pseudobrookiten, og indholdet kan overstige $5 \%$ CuO (tabel 3). Tabel 4 viser analyser af hæmatit i pseudobrookitkorn efter titanomagnetit. De første fire analyser er af hamatitindeslutninger i pseudobrookit, de sidste fire er af større sammenhangende hamatitområder i pseudobrookitkorn. Hæmatitindeslutningerne har lige så lidt $\mathrm{Cu}$ som pseudobrookiten, medens de større sammenhængende hæmatitområder ser ud til at indeholde en lille smule mere $\mathrm{Cu}$. Tabel 5 viser at rutilindeslutningerne i pseudobrookit, såvel efter oprindelig ilmenit som efter oprindelig titanomagnetit, bortset fra et varierende indhold af $\mathrm{Fe}_{2} \mathrm{O}_{3}$, er næsten ren $\mathrm{TiO}_{2}$. Rutil i pseudobrookit efter ilmenit indeholder en lille smule $\mathrm{Cu}$, medens rutil i pseudobrookit efter titanomagnetit er praktisk taget uden Cu.

Tabel 6 viser sammensætningen af den oprindelige ilmenit og delvis af den oprindelige titanomagnetit. Det ses klart at forskellen i $\mathrm{Cu}$ indhold mellem pseudobrookit efter ilmenit og pseudobrookit efter titanomagnetit ikke hidrører fra udgangsmaterialet af ilmenit og titanomagnetit, men må være fremkommet $\mathrm{i}$ forbindelse med pseudobrookitens dannelse.
Ved dannelsen af pseudobrookit fra titanomagnetit afgives der $\mathrm{Fe}$, medens dannelsen af pseudobrookit fra ilmenit er ledsaget af tilførsel af $\mathrm{Fe}$, og den eneste forklaring på forskellen i Cuindhold mellem pseudobrookit efter ilmenit og pseudobrookit efter titanomagnetit der kan gives er at $\mathrm{Cu}(\circ \mathrm{g} \mathrm{Mn})$ følger $\mathrm{Fe}$.

Den høje koncentration af $\mathrm{Cu}$ i hæmatitindeslutninger i pseudobrookit efter ilmenit tages som indicium for, at disse indeslutninger ikke er ureagerede rester, men repræsenterer ufuldstandig omdannelse til pseudobrookit på grund af lokal mangel på Ti for hamatitindeslutningerne, og lokal mangel på Fe for rutilindeslutningerne.

\section{References}

Finger, L. W. 1972: The uncertainty in the calculated ferric iron content of a microprobe analysis. Carnegie Inst. Wash. Yearb. 71, 600-603.

Haggerty, S. E. 1976: Oxidation of opaque mineral oxides in basalts. 1-100 In Rumble, D. (ed.) Oxide Minerals. Min. Soc. Amer., Short course notes. Southern Printing Company, Virginia.

Jensen, Aa. 1978: Compositional variations of the pyroxenes from three flows of Faeroe Islands basalts. Bull. geol. Soc. Denmark 27, Special Issue, 63-78.

Jensen, Aa. 1980: Mineralogical and geochemical variations across three basaltic lava flows from the Faeroe Islands. Bull. Geol. Soc. Denmark 28, 95-114.

Jensen, $\mathrm{Aa}$. 1982: The distribution of $\mathrm{Cu}$ across three basaltic lava flows from the Faeroc Islands Bull. geol. Soc. Denmark 31, 1-10.

Noe-Nygaard, A. 1962: The geology of the Faeroes. Quart. J. geol. Soc. Lond. 118, 375-383.

Noe-Nygaard, A. \& Rasmussen, J. 1968: Petrology of a 3000 metre sequence of basaltic lavas in the Faeroe Islands. Lithos 1, 286-304.

Rasmussen, J. \& Noe-Nygaard, A. 1969: Beskrivelse til Geologisk Kort over Færøerne. Danmarks geol. Unders. 1, 24, 370 pp. (English edition: Geology of the Faeroe Islands. Danmarks geol. Unders. 1, 25, 142 pp.).

Smith, D. G. W. 1965: The chemistry and mineralogy of some emery-like rocks from Sithean Sluaigh, Strachur, Argyllshire. The Amer. Miner. 50, 1982-2022. 